\title{
A Rareposition in Partial Hanging - A Case Report
}

\author{
Dr. S. V. Kuchewar*, Dr. S. H. Bhosle**, Dr. M B Shrigiriwar*** \\ Dr. R D Meshram*, Dr. S J Gadge* \\ * Assistant Professor, Dept of Forensic Medicine, SVNGMC, Yavatmal. \\ ** Assistant Professor, Dept of Forensic Medicine Professor, GMC,Nanded \\ *** Professor \& Head, Dept of Forensic Medicine ,SVNGMC, Yavatmal.
}

\begin{abstract}
In hanging suspension of body may be complete or partial. Different positions of partial hanging are noted in the forensic literature. Here we report a case of 15 year old school going boy who committed suicideby hanging in an unusual way by schooluniform neck-tie as ligature material on the play ground slide. The victim was in lying down position with his whole posterior aspect resting on surface along with head on the play slide. Medico-legal autopsy was done in department of forensic medicineatShriVasantraoNaik Government Medical College, Yavatmal to confirm the cause, mode and manner of death.Medico-legal, legal and social issues related to this rare type of unusual partial hanging case arediscussed.
\end{abstract}

Key worlds: unusual, partial hanging, playground slide, necktie.

\section{Introduction}

Death by hanging is not uncommon andoccurs in all parts of the world.All cases of hanging are considered to be suicidal until the contrary is proved. Whenbody is fully suspended and no part of the body touches the ground then it is calledcomplete hanging, where constricting force isweight of whole body. On the other hand in partial or incomplete hanging, thebody is partially suspended where weight of part of body acts as constricting force. Many cases of partial hanging had been observed and reported by Forensic experts all over world in different positions such as the toes or feettouching the ground or are in a sitting,kneeling, lying down, prone or any otherposture with only head and chest off the ground. In all these positions some part of body was not touching the surface and weight of that part act as constricting force around neck, which resulted into death of deceased.

Hanging is alwayssuicidal in nature until proved otherwise.Occasional cases of homicidal hanging have been reported. Examples have also occurred of people killed in some other way being suspended to simulate hanging (1). Wires, string, pajama, cords, belts, suspenders, scarves, neckties, stockings, and numerous other devices may be used, depending on availability (2). The post-mortemfindings depend on type and site of hanging,nature of the material used, and time ofsuspension.Causes of death due to hanging are airway occlusion,occlusion of veins, compression of the carotid arteries, reflex vagalinhibition and fracture and dislocation ofcervical vertebrae.Here we report a case of 15 year old boy who committed suicidal hanging in an unusual partial hanging position by using school uniform neck-tie as ligature material.

\section{Case History(Fig-1 \& 2)}

This incidence took place in winter 2010 in the Government Medical College Campus area, Yavatmal, Maharashtra (India). As per history given bya resident of government quarters in college campus area,around $6.00 \mathrm{pm}$ he noticed a bicycle with a schoolbag and no one around in the garden. He took a closer look to the place wherehe saw a boy lying over the playground slide in hanging position with his own necktie. The deceased was in lying down position with his whole posterior aspect resting on surface along with head on the play slide. The incidence was informed to nearest police station. As the incidence occurred in our college campus, our team also visited the scene of incidence. By that time the parents \& teachers got information and they arrived at the scene.

Further details about victim were given by his parents. The deceased was 15 years old,a student of $9^{\text {th }}$ class, residing with his parents,. He had attempted suicide by hanging at home few months back. He had told his parents about auditory hallucinations, his thoughts being controlled by imaginary person and about his suicidal thoughts. Parents had psychiatric consultation once and after that did not had any follow ups. Autopsy was conducted at Shri V. N. Government Medical College, Yavatmal

\section{Autopsy Finding (fig-3)}

A well nourished 15 years old male, wearing red shirt\& white pant with green colored school uniform necktie, which was used as a ligature material having fixed noose at left side of neck. Mouth \& eyes were partially opened. Tongue tip in between teeth, with total 28 no of teeth. Rigor mortis present in whole body and 
postmortem lividity was observed over posterior aspect of body more marked over lower limbs. Dried salivary stain was present at right angle of mandible running vertically downward. Face congested and sub-conjunctival hemorrhages seen. The ligature mark oblique, incomplete and above the level of thyroid cartilage running upward backward to left mastoid region measuring $1 \mathrm{~cm}$ in breadth and absent for $6 \mathrm{~cm}$ at left side \&back of neck. The ligature mark was dark reddish brown and parchment like. Apart from ligature mark over neck, no other external injury was evident. Brain and lungs were congested and edematous. Sub pleural and sub pericardial petechial hemorrhages were present.All organs were congested and dark fluid blood was present in heart \& large vessels. The subcutaneous tissues revealed a white glistening area, corresponding to the ligature mark. There was no extravasation of blood in muscles and surrounding tissue. The jugular vein and carotid arteries did not reveal any abnormality or intimal injury. No injury was found in the hyoid bone, thyroid cartilage and cricoidcartilage. The trachea showed slight congestion with little froth within it. There was no injury to cervical vertebrae. Stomach was congested and contained $100 \mathrm{ml}$ yellowish fluid material without any peculiar smell.

\section{Opinion as to cause of death: Asphyxia due to Hanging}

\section{Discussion}

Hanging is a form of ligature strangulation in which the force applied to the neck is derived from a gravitational drag of the weight of the body or part of the body (2). In complete hanging whole body is suspended; no part of the body touches the ground.The term partial hanging is used for such cases in which bodies are partially suspended or those in which bodies are in sitting, kneeling, reclining prone or any other position (3). Partial hanging is taken to be diagnostic of being suicidal in nature (4).

In present case whole body was supported over playground slide surface and nota single part of body was acting as constricting force. In hanging death is commonly caused by compression of the bloodvessels of the neck such that an insufficient amount of oxygenated blood reaches the brain. Obstruction of the airway can also occur, either through compression of the trachea or, when the noose is above the larynx, elevation and posterior displacement of the tongue and floor of the mouth. Blockage or compression of the air passages is not necessary to cause death in hanging. The weight of the head against a noose is sufficient to occlude the carotid arteries and cause death (1).Weight is nothing but the gravitational forces acting on any substance. Polson CJ (5) cited experiments of many workers who opine that tension of 3 to $5 \mathrm{Kg}$ is enough to obstruct jugular veins \& carotid arteries and about $16 \frac{1 / 2}{2}$ to $30 \mathrm{Kg}$ to obstruct vertebral arteries. While trachea closes by a tension of 15 $\mathrm{Kg}$.

Khokhlov VD (6) modeled human body as a complex of 16 freely joined hard parts and calculated the tension exerted on ligature in different positions of incomplete hanging. He commented that in standing posture the ligature is stretched by more than $65 \%$ of the body weight, in kneeling position by $64-74 \%$, in sitting by 17 $32 \%$, in recumbent posture by less than $18 \%$ of body weight.

In the present case though his whole body was resting on surface of the play slide,Slantingposition had produced sufficient constricting force resulted in compression of neck vessels which was supported by feature of facial congestion,sub-conjunctival hemorrhage. There was also obstruction of airway resulting from elevation and displacement of the tongue \& floor of mouth.

In present case we noted dribbling of saliva from right angle of mouth, parchmentisation of skin at the ligature site with petechial hemorrhages at upper border of ligature mark, signs of central cyanosis, congestion of all visceral organs with fluidity of blood and Cerebro-pulmonary oedema with subpleural\&subpericardialpetechiae. All these findings are in favour of ante-mortem and suicidal in nature.

The necktie of school uniform was used by boy for committing suicide, had raised the suspicion of accidental hanging. As the boy was not wearing school uniform, tie was firmly tied with multiple knots to suspension point and the fixed type of noose at one end ruled out accidental hangings. The ligature material used to commit suicide by hanging could be anything available at that moment which was necktie in present case. This signifies that the act was impulsive and no preparation was done for hanging.

The boy in the present study case had previous suicidal attempt, suicidal ideation which had been told by him to parents. Complaints about auditory hallucinations, his thoughts being controlled by imaginary person, being continuously instructed by someone suggested that victim was suffering from some psychiatric illness (7) for which regular psychiatric consultations was necessary. In this case the victim had consulted the psychiatrist once but due to illiteracy, ignorance\& low socioeconomic status of parent further follow-up was not done. If the psychiatrists help had been taken with proper follow-up the incidence could have been avoided.

\section{Conclusion}

Partial hanging is almost always suicidal in nature. Hanging is most frequently observed since it is commonly chosen as a method of suicide. Partial hanging can be possible in different positions such as the toes or feet touching the ground or are in a sitting, kneeling, lying down, prone or any other posture with only head 
and chest off the ground and also present unusual position. Development of sufficient force constricting neck for causing death is most important factor for completion of act.

\section{References}

[1]. DiMaioVJ and DiMaioD.Forensic Pathology. Second Edi. Boca Raton: CRC Press; 2001. p. 262-71.

[2]. SaukkoP and Knight B. Knight's Forensic Pathology. Third Ed. London: Arnold Publishers; 2004. p. 352-394

[3]. Modi'sMedical Jurisprudence and Toxicology.Karmakar RN and Patnaik AK editor. Twenty-Third Ed. New Delhi: LexisNexis; 2007. p. 565-75

[4]. Nandy A. Principles of Forensic Medicine including Toxicology. Third Ed. London: New Central Book Agency (P) Ltd; 1985. p. 517-29.

[5]. Polson CJ, Gee DJ and Knight B. The Essentials of Forensic Medicine. Forth Ed. Oxford: Pergamon Press; 1985. p. 357-89.

[6]. Khokhlov VD. Calculation of tension exerted on Ligature in Incomplete Hanging. Forensic Science International. 2001; 123:17277.

[7]. Vyas JN and Ahuja N. Postgraduate Psychiatry. First Ed. New Delhi: B. I. Churchill Livingstone Pvt Ltd; 1992. p. $332-342$.

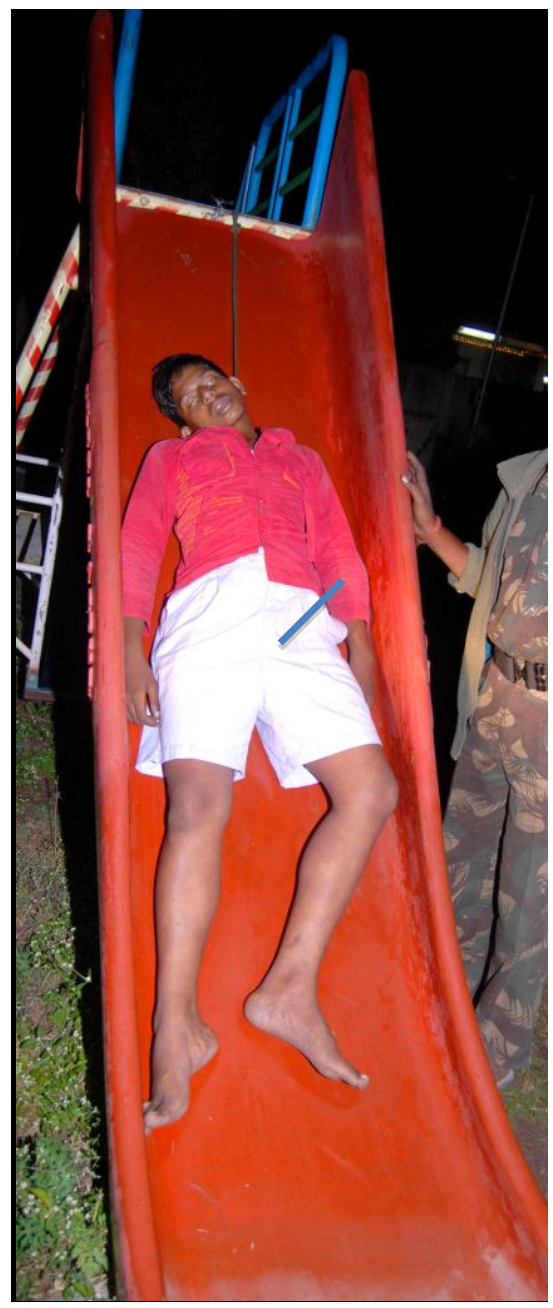

Fig-1-Partial hanging over Play-slide 


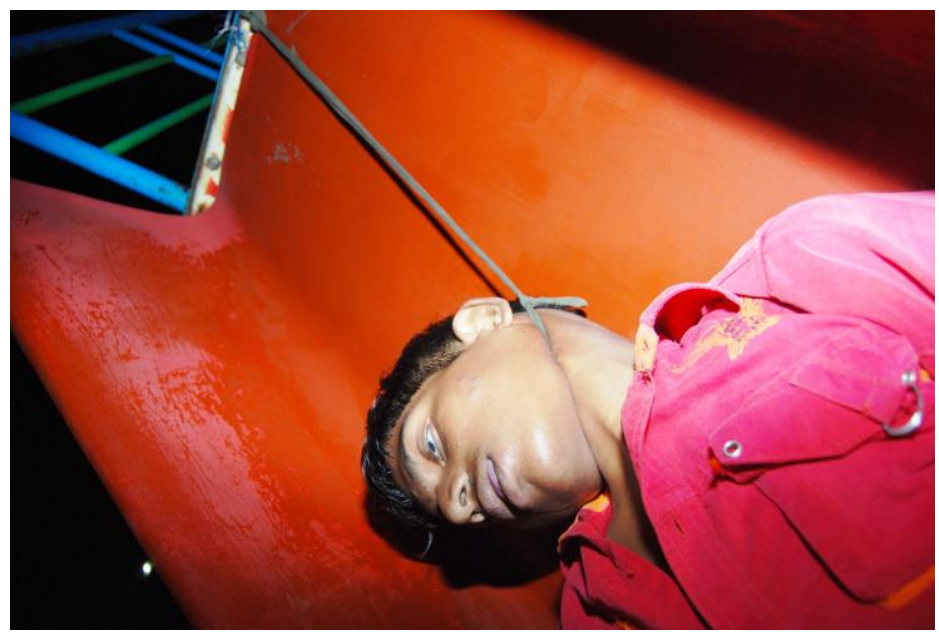

Fig-2 - Ligature material (neck-tie) with fixed noose

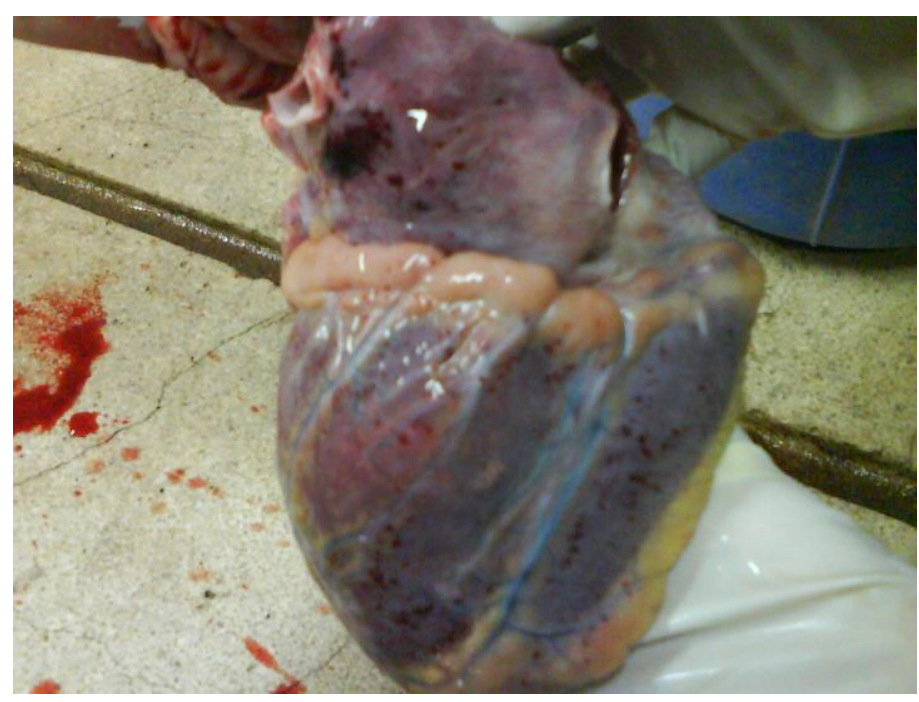

Fig-3- Petechial hemorrhage over heart 